AJIE - Asian Journal of Innovation and Entrepreneurship

(e-ISSN: 2477- 0574; p-ISSN: 2477-3824)

Vol. 02, No. 01, January 2017

\title{
IPTEKS BAGI MASYARAKAT (IBM) \\ KELOMPOK IBU-IBU RUMAH TANGGA DESA BANJAREJO KECAMATAN NGADILUWIH KABUPATEN KEDIRI
}

\author{
Mochamad Syaiful Arif ${ }^{1)}$, Yanuar Fauzuddin ${ }^{2}$. \\ ${ }^{1}$ Faculty of Business and Economics, Wijaya Putra University \\ ${ }^{2}$ Faculty of Business and Economics, Wijaya Putra University \\ Corresponding E-mail: msyarif.owl@gmail.com
}

\begin{abstract}
These outreach activities conducted in the framework of community empowerment of Banjarejo village, Ngadiluwih district, Kediri Regency. Banjarejo village is one of the villages that are in Ngadiluwih Subdistrict, district of Kediri. Banjarejo village has an area of $3 \mathrm{~km}^{2}$ with a population of 4800 inhabitants and 1353 households. The community of the village Banjarejo the majority of the profession as farmers (especially sugar cane farmers) and the land that is tilled land belonging to other people, so the resulting income is for the results with the landlord. Mothers day activities in the hamlet of Banjarejo is as housewives, so that family income depends only on the results of farming done the head of the family. Low productivity and earnings are still below the average UMK (Minimum Wage) make the economic conditions of the community of the village Banjarejo are below average. The low income community also makes it difficult to create field efforts independently. The situation of the Islamic religion which is very pronounced in the environs of the village made the village Banjarejo has the potential of local wisdom. In addition, sewing skills possessed some housewives in the hamlet of Banjarejo can provide potential business ventures. These outreach activities aim to increase productivity and income through Banjarejo Village society empowerment mother-housewife. By using the minimum skills in terms of tailoring which dikolaborasikan with the local wisdom, then tailoring business activities diwujudkanlah fashions will be done by a group of mothers of households of the village Banjarejo. Partners are divided into two groups, each group consists of three cadres housewife. Activities carried out through counseling, capital assistance, training and mentoring. Outreach is done in order to add insights about the fashion and entrepreneurship. Capital assistance granted to support operational business activities in the form of a sewing machine and raw fabric and yarn. Training conducted to improve the competencies of the partners in terms of tailoring and management efforts. Whereas mentoring is done to maintain consistency, help overcome difficulties and give the spirit of trying to group partners. The result of this activity is to increase the productivity and income of the Group assisted SMEs. Furthermore, the results of these activities are expected to create employment for the whole community of the village Banjarejo, so there is an increase in earnings and productivity for the whole community of the village Banjarejo. Development of business activities can create a hub of muslim fashion in the hamlet of Banjarejo so that it will come true convection tourism for domestic and foreign tourists.
\end{abstract}

Keywords: Enterpreneurship, Housewifes, Tailor, SME, Kediri 


\begin{abstract}
ABSTRAK
Kegiatan penjangkauan ini dilakukan dalam rangka pemberdayaan masyarakat desa Banjarejo, Kecamatan Ngadiluwih, Kabupaten Kediri. Desa Banjarejo adalah salah satu desa yang ada di Kecamatan Ngadiluwih, Kabupaten Kediri. Desa Banjarejo memiliki luas $3 \mathrm{~km} 2$ dengan jumlah penduduk 4800 jiwa dan 1353 rumah tangga. Masyarakat desa Banjarejo mayoritas profesi sebagai petani (terutama petani tebu) dan tanah yang digarap tanah milik orang lain, sehingga pendapatan yang dihasilkan untuk hasil dengan pemilik. Ibu hari kegiatan di dusun Banjarejo adalah sebagai ibu rumah tangga, sehingga pendapatan keluarga hanya bergantung pada hasil pertanian dilakukan kepala keluarga. produktivitas dan pendapatan rendah masih di bawah rata-rata UMK (Upah Minimum) membuat kondisi ekonomi masyarakat desa Banjarejo bawah rata-rata. Masyarakat berpenghasilan rendah juga membuat sulit untuk membuat upaya lapangan secara mandiri. Situasi agama Islam yang sangat terasa di lingkungan desa membuat desa Banjarejo memiliki potensi kearifan lokal. Selain itu, keterampilan menjahit yang dimiliki beberapa ibu rumah tangga di dusun Banjarejo dapat memberikan potensi usaha bisnis. kegiatan penjangkauan ini bertujuan untuk meningkatkan produktivitas dan pendapatan melalui Desa Banjarejo pemberdayaan masyarakat ibu-ibu rumah tangga. Dengan menggunakan keterampilan minimum dalam hal menjahit yang dikolaborasikan dengan kearifan lokal, kemudian menjahit kegiatan usaha diwujudkanlah mode akan dilakukan oleh sekelompok ibu-ibu rumah tangga dari desa Banjarejo. Mitra dibagi menjadi dua kelompok, masingmasing kelompok terdiri dari tiga kader ibu rumah tangga. Kegiatan yang dilakukan melalui penyuluhan, bantuan modal, pelatihan dan mentoring. Outreach ini dilakukan dalam rangka untuk menambah wawasan tentang fashion dan kewirausahaan. bantuan modal yang diberikan untuk mendukung kegiatan bisnis operasional dalam bentuk mesin jahit dan kain mentah dan benang. Pelatihan dilakukan untuk meningkatkan kompetensi para mitra dalam hal menjahit dan upaya manajemen. Sedangkan mentoring dilakukan untuk menjaga konsistensi, membantu mengatasi kesulitan dan memberikan semangat berusaha mitra kelompok. Hasil dari kegiatan ini adalah untuk meningkatkan produktivitas dan pendapatan dari UKM Grup dibantu. Selanjutnya, hasil dari kegiatan ini diharapkan dapat menciptakan lapangan kerja bagi seluruh masyarakat desa Banjarejo, sehingga ada peningkatan pendapatan dan produktivitas bagi seluruh masyarakat desa Banjarejo. Pengembangan kegiatan usaha dapat membuat hub fashion muslim di Dusun Banjarejo sehingga akan datang pariwisata konveksi berlaku untuk wisatawan domestik dan asing.
\end{abstract}

Kata kunci: Enterpreneurship, ibu rumah tangga, Tailor, UKM, Kediri

\section{PENDAHULUAN}

\section{Analisis Situasi}

Desa Banjarejo merupakan salah satu desa yang ada di Kecamatan Ngadiluwih, Kabupaten Kediri. Desa Banjarejo memiliki luas 3 (tiga) $\mathrm{km}^{2}$ dengan jumlah penduduk sebesar 4800 jiwa dan 1353 rumah tangga (BPS Kabupaten Kediri, 2014). Desa Banjarejo memiliki 4 (empat) dusun, yaitu Dusun Banjarejo, Dusun Trate, Dusun Kendaldoyong dan Dusun Paras. Menurut Kepala Desa Banjarejo, Dusun Paras, Kendaldoyong dan Dusun Trate, penduduknya telah mandiri secara ekonomi melalui usaha tanaman hias dan pembuatan tiang bangunan (cor). Sedangkan Dusun Banjarejo mayoritas penduduk laki-lakinya berprofesi sebagai petani (khususnya petani 
tebu) dan penduduk perempuannya mayoritas hanya sebagai ibu rumah tangga. Sebagai petani, mayoritas penduduk Dusun Banjarejo menggarap sawah atau ladang yang bukan miliknya, sehingga penghasilan yang didapatkan merupakan bagi hasil dengan pemilik tanah garapan. Hal ini yang membuat penghasilan dusun tersebut masih di bawah rata-rata, sehingga diantara keempat dusun, masyarakat Dusun Banjarejo memiliki tingkat ekonomi di bawah rata-rata. Menurut data kelurahan setempat, 60\% penduduk Dusun Banjarejo memiliki pendidikan terakhir setingkat SMA, 40\% lainnya di bawah tingkat SMA. Hal ini menjadi salah satu faktor kesulitan penduduk dusun tersebut untuk bekerja dibidang industri perkotaan.

Dengan segala bentuk kesederhanaannya, kehidupan sosial dan budaya masyarakat Dusun Banjarejo sangat harmonis. Nuansa religi sangat terasa dengan ditunjukkannya kesadaran masyarakat dusun yang berbondongbondong menuju masjid untuk sholat berjamaah ketika telah tiba waktu sholat. Kondisi ini didukung dengan adanya pondok pesantren kecil yang telah memiliki beberapa santri, sehingga menurut Kepala Desa, hampir tidak terdapat konflik sosial yang berarti di dusun tersebut. Kegiatan sehari-hari masyarakat Dusun Banjarejo adalah bertani (laki-laki), sedangkan untuk para ibu menjalankan perannya sebagai ibu rumah tangga, yaitu membersihkan rumah, mencuci dan memasak serta merawat anak. Saling bertegur sapa antar tetangga ketika bertemu telah menjadi budaya yang membuat suasana dusun menjadi hangat dan nyaman. Kondisi ini seakan-akan menyamarkan kondisi ekonomi masayarakat dusun yang masih di bawah rata-rata.
Menurut informasi yang didapat tim pengusul, selama ini terdapat beberapa kegiatan penyuluhan dan pelatihan yang dilakukan dinas pemerintahan setempat, seperti yang dilakukan oleh Diskoperindag (Dinas Koperasi, Perindustrian dan Perdagangan) Kabupaten Kediri pada akhir tahun 2014, yaitu pelatihan menjahit bagi ibu-ibu rumah tangga Desa Banjarejo. Karena terbatasnya kuota, maka pihak Dusun Banjarejo hanya mengirimkan 6 (enam) ibu rumah tangga. Keterampilan yang didapatkan dari pelatihan itu tidak dapat dimanfaatkan secara optimal, bahkan tidak teraplikasikan sama sekali. Hal ini dikarenakan pelatihan yang diberikan tidak dilanjutkan dengan pendampingan berwirausaha dan bantuan peralatan, sehingga keterampilan yang diberikan hanya menjadi sebatas pengalaman saja. Informasi ini mengarahkan tim pengusul untuk mengadakan kegiatan IbM (IPTEKS bagi Masyarakat) Dusun Banjarejo dalam rangka pemberdayaan masyarakat (dalam hal ini kelompok ibu-ibu rumah tangga) untuk mendirikan usaha dibidang penjahitan sehingga akan mampu meningkatkan kemandirian usaha yang berdampak pada meningkatnya kesejahteraan ekonomi keluarga. Lebih jauh lagi, pengembangan usaha dibidang tata busana tersebut akan mampu menciptakan lapangan pekerjaan, khususnya bagi masyarakat Dusun Banjarejo. Selain menyesuaikan dengan potensi keterampilan yang telah dimiliki oleh masyarakat, kegiatan ini juga dilakukan berbasis kearifan lokal, yaitu religi. Dengan kehidupan sosial masyarakat Dusun Banjarejo yang bernuansa islami, tim pengusul mengarahkan usaha penjahitan yang akan dibangun untuk memproduksi busana muslim, sehingga 
kedepannya akan dapat dikembangkan menjadi sentra konveksi busana muslim.

Pasar busana muslim telah menjamur di Indonesia, mengingat mayoritas penduduknya beragama islam. Busana muslim telah menjangkau berbagai kalangan, mulai dari anak-anak, remaja, dewasa hingga lansia. Di Kota dan Kabupaten Kediri sendiri, nuansa religi islami sudah menjadi warna khusus yang mencerminkan budaya lokal. Hal ini ditunjukkan dengan terdapatnya salah satu pondok pesantren terbesar di Indonesia, yaitu Pondok Pesantren Lirboyo. Selain itu Kota dan Kabupaten Kediri juga dikelilingi oleh beberapa daerah religi, seperti Jombang dan Blitar, sehingga pemasaran busana muslim untuk wilayah Kediri dan sekitarnya memberikan potensi yang cukup besar. Dari sisi kebutuhan, pakaian (sandang) merupakan salah satu kebutuhan pokok manusia disamping makanan (pangan) dan tempat tinggal (papan), sehingga usaha dibidang tata busana akan selalu memberikan peluang yang menjanjikan. Di kota-kota besar telah banyak mal yang memiliki moeslem center (pusat asesoris busana muslim). Di samping itu, perilaku perdagangan secara online melalui media-media sosial menunjukkan penjualan busana muslim yang sangat ramai. Kondisi-kondisi ini membuat busana muslim masih memiliki pasar yang sangat luas.

Sasaran dari kegiatan ini adalah masyarakat yang kurang produktif, yaitu ibu-ibu rumah tangga Dusun Banjarejo sebanyak 2 (dua) kelompok. Tiap kelompok terdiri dari 3 (tiga) kader dengan kualifikasi memiliki keterampilan menjahit, minimal keterampilan menjahit dasar. Secara implementasi, kegiatan ini dilakukan mulai dari hulu hingga hilir, yaitu mulai dari pemantapan komitmen dan pelatihan, proses produksi hingga pemasaran, yang meliputi penyuluhan kewirausahaan, bantuan peralatan dan bahan, pelatihan menjahit lanjutan, pembuatan produk awal, pendampingan proses produksi, pelatihan pengelolaan keuangan, pendampingan pemasaran dan pendampingan pengurusan izin usaha. Profil kelompok mitra kegiatan ditunjukkan pada tabel di bawah ini.

Tabel 1.1

Profil Mitra I

\begin{tabular}{|c|c|c|c|c|}
\hline Nama & $\begin{array}{c}\text { Usia } \\
\text { (Tahun) }\end{array}$ & $\begin{array}{c}\text { Pendidikan } \\
\text { Terakhir }\end{array}$ & \multicolumn{2}{|r|}{ Alamat } \\
\hline $\begin{array}{l}\text { Umi Dwi } \\
\text { Susyanti }\end{array}$ & 37 & SMA & $\begin{array}{c}\text { RT } 002 \text { / RW } \\
001\end{array}$ & \multirow{3}{*}{$\begin{array}{l}\text { Dusun Banjarejo, Desa } \\
\text { Banjarejo, Kecamatan } \\
\text { Ngadiluwih, Kabupaten } \\
\text { Kediri }\end{array}$} \\
\hline $\begin{array}{l}\text { Titik } \\
\text { Umiyati }\end{array}$ & 35 & SMA & $\begin{array}{c}\text { RT } 002 \text { / RW } \\
001\end{array}$ & \\
\hline Sulistiani & 35 & SMP & $\begin{array}{c}\text { RT } 001 / \text { RW } \\
001\end{array}$ & \\
\hline
\end{tabular}


Profil Mitra II

\begin{tabular}{|l|c|c|c|l|}
\hline \multicolumn{1}{|c|}{ Nama } & $\begin{array}{c}\text { Usia } \\
\text { Tahun } \\
\text { ) }\end{array}$ & $\begin{array}{c}\text { Pendidikan } \\
\text { Terakhir }\end{array}$ & \multicolumn{2}{|c|}{ Alamat } \\
\cline { 1 - 4 } $\begin{array}{l}\text { Ekowati } \\
\text { Setyoningsi } \\
\text { h }\end{array}$ & 48 & SMA & $\begin{array}{c}\text { RT 001 / RW } \\
001\end{array}$ & $\begin{array}{l}\text { Dusun Kendal Doyong, Desa } \\
\text { Banjarejo, Kecamatan } \\
\text { Ngadiluwih, Kabupaten Kediri }\end{array}$ \\
\hline Ipa Indarti & 39 & SMA & $\begin{array}{c}\text { RT 001/RW } \\
001\end{array}$ & \\
\cline { 1 - 4 } $\begin{array}{l}\text { Triana } \\
\text { Komalasari }\end{array}$ & 36 & SMA & $\begin{array}{c}\text { RT 001 / RW } \\
002\end{array}$ & \\
\hline
\end{tabular}

\section{Potensi Lingkungan}

\section{Aspek Lingkungan}

a. Lingkungan kelompok mitra (Dusun Banjarejo) yang bernuansa religi sangat islami.

b. Jarak yang relatif dekat dengan pusat $\operatorname{kota}( \pm 10 \mathrm{~km})$

c. Dekat dengan jalan raya antar kota (Kediri-Tulungagung dan Kediri-Blitar).

d. Memiliki salah satu pondok pesantren terbesar di Pulau Jawa (Pondok Pesantren Lirboyo) yang mempengaruhi tingginya budaya islam di Kota/Kabupaten Kediri.

e. Dekat dengan Kota/Kabupaten yang juga memiliki budaya islam yang tinggi, yaitu Kabupaten Jombang dan Bltar.

f. Kota/Kabupaten Kediri memiliki wisata bangunan Paris Van Java dan Gunung Kelud.

\section{Aspek Keterampilan}

a. Memiliki keterampilan menjahit dasar.

b. Memiliki keterampilan mendesain pakaian.

c. Memiliki keterampilan mengobras.

\section{Aspek Produktifitas}

a. Memiliki waktu yang sangat luang.

b. Masih memiliki usia produktif.

\section{Aspek Aset}

Memiliki ruang yang cukup luas untuk digunakan sebagai tempat proses penjahitan.

\section{Permasalahan}

a. Penghasilan keluarga yang dimiliki masih dibawah rata-rata UMK Kabupaten Kediri, yaitu $\pm \mathrm{Rp}$. 1.000.000,- / bulan.

b. Tidak produktif secara ekonomi, karena hanya berperan sebagai ibu rumah tangga.

c. Hanya memiliki keterampilan menjahit tingkat dasar.

d. Tidak memiliki peralatan dan bahan baku untuk melakukan usaha penjahitan, seperti mesin jahit, mesin obras, mesin bordir dan meteran.

e. Penghasilan yang masih di bawah ratarata membuat mitra tidak dapat melakukan pengadaan peralatan dan bahan baku untuk melakukan kegiatan usaha

f. Dusun Banjarejo belum memiliki produk unggulan yang dapat meningkatkan kegiatan ekonomi masyarakat.

g. Belum pernah memiliki kegiatan usaha secara mandiri, sehingga tidak memiliki 
pengetahuan dan keterampilan dalam menjalankan usaha.

\section{METODE PELAKSANAAN}

Kegiatan ini dilakukan dengan metode pemberdayaan masyarakat, yaitu penyuluhan, pelatihan bantuan modal dan pendampingan. Dengan metode ini maka kegiatan akan mencakup keseluruhan usaha mulai dari hulu hingga hilir, sehingga apa yang telah diusahakan dapat memberikan hasil yang nyata. Secara umum, permasalahan yang dihadapi mitra adalah kondisi ekonomi yang masih di bawah ratarata dan tingkat produktivitas yang masih rendah. Untuk mengatasi permasalahan tersebut, tim pengusul memberikan solusi berupa membangun lapangan usaha yang disesuaikan dengan keterampilan minimum masyarakat dan berbasis kearifan lokal daerah mitra. Sasaran kegiatan ini adalah ibu-ibu rumah tangga dengan tujuan meningkatkan produktivitas ekonomi keluarga, yang mana pada awalnya kegiatan ibu-ibu rumah tangga ini hanya melakukan pekerjan rumah tangga, maka kini diarahkan untuk memiliki kegiatan yang dapat menghasilkan pendapatan finansial. Dari hal tersebut maka ditentukanlah kegiatan yang mampu meningkatkan produktivitas ekonomi dan berbasis kearifan lokal, yaitu usaha penjahitan busana muslim dengan sistem konveksi. Guna mengatasi permasalahanpermasalahan yang ada dan mewujudkan bidang usaha yang ditentukan, dilakukan dengan metode yang diuraikan berikut ini.

\section{Penanaman Perilaku Kewirausahaan}

Kelompok mitra merupakan masyarakat yang tidak memiliki pengalaman dalam berwirausaha. Oleh karena itu sebelum melakukan kegiatan yang mengarah pada kegiatan bisnis, maka perlu ditanamkan jiwa kewirausahaan sehingga tumbuh perilaku-perilaku yang mengarah kepada perilaku kewirausahaan. Penanaman jiwa kewirausahaan yang dilakukan tim pengusul adalah melalui penyuluhan dan diskusi serta berbagi pengalaman. Berikut metode penyuluhan yang digunakan.

a. Tim pengusul melakukan presentasi secara teoritis mengenai materi kewirausahaan dengan menunjukkan gambaran-gambaran nyata mulai dari memulai usaha hinga mempertahankannya.

b. Berbagi pengalaman dengan salah satu tim pengusul, yaitu Mochammad Syaiful Arif yang memiliki usaha sampingan berupa usaha laundry.

c. Diskusi dan tanya jawabantara tim pengusul dan kelompok mitra mengenai segala hal yang terkait dengan membangun usaha baru.

d. Evaluasi dari tim pengusul mengenai kesungguhan kelompok mitra dalam memulai usaha.

Dalam kegiatan penyuluhan kewirausahaan ini, kelompok mitra harus pro aktif dalam mengajukan pertanyaan-pertanyaan dan berdiskusi.

\section{Bantuan Modal Peralatan, Perlengkapan dan Bahan Baku}

Dengan kondisi ekonomi masyarakat yang masih di bawah rata-rata, tentunya kelompok mitra memiliki kesulitan dalam mengadakan peralatan dan bahan baku untuk memulai usaha. Walaupun kegiatan produksi dan pemasaran belum dilakukan, namun perlatan dan bahan baku produksi diperlukan untuk memberikan pelatihan secara riil kepada kelompok mitra. Oleh karenanya setelah ditanamkan jiwa kewirausahaan, maka tim pengusul memberikan bantuan peralatan dan bahan 
baku produksi. Bantuan modal yang dilakukan di awal kegiatan juga akan mampu meningkatkan motivasi kelompok mitra dalam menjalankan usaha. Berikut langkah-langkah tim pengusul dalam memberikan bantuan modal.

a. Tim pengusul, calon trainer tata busana dan kelompok mitra, bersama-sama mengunjungi toko peralatan dan perlengkapan penjahitan. Calon trainer tata busana akan membantu menentukan spesifikasi mesin jahit yang sesuai dengan kebutuhan. Kelompok mitra akan mendapatkan pelatihan singkat dari penjual mesin jahit mengenai bagaimana cara mengoperasikan dan merawat mesin tersebut.

b. Tim pengusul beserta calon trainer tata busana, bersama-sama mengunjungi toko bahan baku penjahitan, yaitu kain dan benang. Calon trainer tata busana akan membantu menentukan kebutuhan bahan baku yang akan digunakan sebagai bahan baku pelatihan menjahit.

c. Peralatan produksi berupa mesin jahit dikirim oleh penjual ke alamat ketua kelompok mitra dan diserah terimakan oleh tim pengusul.

Bantuan bahan baku untuk proses produksi masal akan diberikan ketika kelompok mitra telah dinyatakan mampu oleh trainer tata busana dan produk awal yang dihasilkan dinilai layak jual oleh trainer tata busana.

\section{Peningkatan Keterampilan}

Seluruh kelompok mitra pernah mendapatkan keterampilan menjahit dari pelatihan menjahit yang diadakan oleh Diskoperindag (Dinas Koperasi, Perindustrian dan Perdagangan) Kabupaten Kediri. Namun keterampilan yang didapatkan tersebut dinilai masih minim sehingga belum layak untuk membuat produk busana muslim yang layak jual. Oleh karena itu pelatihan secara intensif sangat dibutuhkan guna memiliki keterampilan kelompok mitra sesuai dengan kebutuhan produksi busana muslim. Berikut tahapan yang dilakukan dalam rangka peningkatan keterampilan menjahit kelompok mitra.

a. Trainer tata busana memberikan pengetahuan dan pemahaman kepada kelompok mitra mengenai hal-hal yang terkait dengan desain pakaian muslim, baik pakaian pria maupun wanita. Pengetahuan dan pemahaman yang diberikan meliputi jenis-jenis kain, jenis-jenis benang dan model-model busana muslim yang sedang tren.

b. Trainer tata busana memberikan keterampilan kelompok mitra dalam menggambar desain busana muslim. Kemudian kelompok mitra diberikan waktu untuk mengambar desainnya sendiri yang akan dinilai oleh trainer.

c. Trainer tata busana memberikan keterampilan kepada kelompok mitra dalam membuat mal pakaian dengan bahan baku kertas koran hingga kelompok mitra mampu mengaplikasikannya sendiri.

d. Trainer tata busana memberikan keterampilan memotong bahan baku kain kepada kelompok mitra sesuai dengan bentuk mal yang telah dibuat hingga kelompok mitra mampu mengaplikasikannya sendiri sesuai dengan standar dari trainer.

e. Trainer tata busana memberikan pelatihan menjahit kepada kelompok mitra, mulai dari teknik menjahit, mengobras, memberikan motif bordir hingga finishing. Produk hasil pelatihan akan dinilai oleh trainer dan kelompok mitra akan terus membuat produk awal 
hingga dinilai oleh trainer bahwa produk yang dihasilkan layak jual.

f. Selama pelatihan menjahit berlangsung, tim pengusul mengamati proses menjahit yang dilakukan sebagai bahan informasi bagi tim pengusul dalam mendesain proses produksi penjahitan yang efektif dan efisien. Desain proses produksi yang dibuat akan ditransfer kepada kelompok mitra pada kegiatan berikutnya.

Setelah kelompok mitra dinilai mampu untuk membuat busana muslim yang layak jual, maka selanjutnya kelompok mitra melakukan produksi busana muslim secara masal yang sebelumnya akan mendapatkan pemahaman mengenai manajemen usaha oleh tim pengusul.

\section{Pelatihan dan Pendampingan Manajemen Usaha}

Keterampilan dan modal usaha tidaklah cukup untuk menjalankan suatu usaha bisnis. Melainkan diperlukan kemampuan pengelolaan usaha yang baik dan berkelanjutan. Oleh karenanya, selain peningkatan keterampilan dan bantuan modal usaha, tim pengusul memberikan pelatihan kepada kelompok mitra mengenai bagaimana mengelola usaha secara tepat. Selain itu tim pengusul juga memberikan pendampingan kepada kelompok mitra dalam menjalankan usaha sesuai dengan jangka waktu yang ditentukan dalam pelaksanaan kegiatan IbM (IPTEKS bagi Masyarakat). Pendampingan dilakukan supaya kesulitan-kesulitan yang dihadapi mitra dalam menjalankan usaha dapat segera terselesaikan, sehingga transfer pengetahuan dan teknologi kepada mitra dapat dilaksanakan secara optimal. Berikut tahapan-tahapan pelatihan dan pendampingan manajemen usaha yang dilakukan tim pengusul terhadap kelompok mitra.

a. Tim pengusul mentransfer pengetahuan tentang desain proses produksi menjahit yang telah dibuat sebelumnya kepada kelompok mitra. Proses transfer yang dilakukan dengan cara memaparkan desain yang telah dibuat kepada kelompok mitra, kemudian menjelaskan secara detail mengenai bagian-bagian proses produksi yang ditunjukkan. Penjelasan disertai dengan sebab akibat yang terjadi antara jika tidak memiliki desain dengan proses produksi yang telah didesain sedemikian rupa.

b. Tim pengusul memberikan pengetahuan dan pemahaman kepada kelompok mitra mengenai cara menentukan beban biaya produksi, besaran keuntungan dan harga jual produk.

c. Tim pengusul memberikan keterampilan kepada kelompok mitra dalam membuat pencatatan keuangan usaha mikro kecil, meliputi neraca arus kas, neraca laba rugi dan laporan keuangan.

d. Tim pengusul memberikan pengetahuan dan pemahaman kepada kelompok mitra mengenai strategi pemasaran produk.

e. Setelah beberapa produk selesai dibuat, kelompok mitra diberikan keterampilan dalam memfoto produk jadi yang kemudian diunggah ke media sosial untuk dipasarkan.

f. Tim pengusul memberikan bantuan kepada kelompok mitra berupa brosur katalog produk yang digunakan untuk pemasaran secara langsung kepada konsumen.

g. Tim pengusul melakukan pendampingan kegiatan pemasaran secara langsung ke toko-toko busana muslim dan konsumen perorangan. Untuk konsumen perorangan, pendampingan tim pengusul terhadap mitra dilakukan pada 
lokasi-lokasi wisata dan car free day event yang diadakan oleh pemerintah setiap hari minggu pagi di pusat kota.

Kelompok mitra dengan didampingi tim pengusul melakukan pengurusan izin usaha yaitu Izin Usaha Mikro dan Kecil di kantor Kecamatan Ngadiluwih.

\section{HASIL PELAKSANAAN}

Berikut hasil yang dicapai dalam kegiatan IbM Kelompok Ibu-Ibu Rumah Tangga Desa Banjarejo Kabupaten Kediri.

\section{Keterampilan}

Seluruh kelompok mitra telah diberikan pelatihan secara intensif selama 1 minggu dengan materi desain busana; membuat pola (mal); memotong kain; pengoperasian mesin jahit dan obras; menjahit dan mengobras serta menyeterika. Untuk keterampilan membordir tidak dapat diberikan dikarenakan pengadaan mesin bordir tidak mampu dilakukan yang disebabkan tingginya kenaikan harga mesin sehingga tidak sesuai dengan estimasi anggaran awal. Pelatihan dilakukan dengan menggunakan jasa trainer privat karena pertimbangan biaya yang lebih murah dan waktu yang lebih efisien dibandingkan mendaftarkan kursus menjahit. Kemampuan produksi yang didapatkan adalah jenis produk baju muslim wanita (gamis); kerudung; bantal; sarung tempat tisu dan bros.

\section{Modal Usaha}

Masing-masing kelompok mitra telah memiliki modal usaha berupa :

1. Mesin jahit (1 unit)

2. Mesin obras (1 unit)

3. Meja mesin jahit (2 unit)

4. Meteran kain (2 buah)

5. Penggaris mal (2 set)

6. Kain $(30 \mathrm{~kg})$

7. Benang (10 gulung)

\section{Kewirausahaan}

Di awal pelaksanaan kegiatan terdapat 2 orang dari kelompok mitra 2 yang mengundurkan diri sehingga harus dicarikan pengganti. Formasi kelompok mitra yang baru dapat dilihat pada tabel di bawah. Setelah mendapat formasi yang baru Tim Pengusul memberikan penguatan komitmen dengan memberikan wawasan mengenai manfaat berwirausaha. Masingmasing kelompok mitra telah berhasil membuat baju muslim wanita (gamis) dan kerudung pada saat sesi pelatihan. Produk yang dihasilkan oleh seluruh kelompok mitra telah dinilai layak jual oleh trainer walaupun belum layak untuk memasuki pasar sekelas Mall. Dari bulan Agustus hingga awal November, masing-masing mitra telah mampu menjual dan mendapatkan omset rata-rata Rp.1.500.000,-/bulan. Hal ini belum sesuai harapan karena persaingan pasar cukup ketat dan kualitas produk yang dihasilkan belum mampu bersaing di pasar yang lebih luas.

\section{Manajemen Usaha \\ MITRA I}

a. Spesifikasi produk Baju Gamis dan Jilbab

b. Harga Jual

Gamis : 50-75 ribu/baju

Jilbab : 15-35 ribu/jilbab

c. Rata-rata penjualan per bulan

Gamis : 10-20 baju/bulan

Jilbab : 20-50 jilbab/bulan

\section{MITRA II}

a. Spesifikasi produk

Baju Gamis, Jilbab dan Tas

b. Harga Jual

Gamis : 50-75 ribu/baju

Jilbab : 15-35 ribu/jilbab

Tas : 75-150 ribu/tas

c. Rata-rata penjualan per bulan 
Gamis : 10-20 baju/bulan

Jilbab : 20-50 jilbab/bulan

Tas : 1-2 tas/bulan

Data penjualan sebagai berikut :

\section{MITRA I}

\section{Bulan Agustus}

$\begin{array}{ll}\text { Baju Gamis } & \text { 10 Baju } \\ \text { Jilbab } & \text { 20 Jilbab } \\ \text { Total Pendapatan } & \text { Rp. 800.000,- } \\ \text { Bulan September } & \\ \text { Baju Gamis } & \text { 15 Baju } \\ \text { Jilbab } & \text { 35 Jilbab } \\ \text { Total Pendapatan } & \text { Rp. 1.700.000,- } \\ \text { Bulan Oktober } & \\ \text { Baju Gamis } & \text { 20 Baju } \\ \text { Jilbab } & \text { 50 Jilbab } \\ \text { Total Pendapatan } & \text { Rp. 2.375.000,- }\end{array}$

\section{Bulan November (Tanggal 7)}

$\begin{array}{ll}\text { Baju Gamis } & 2 \text { Baju } \\ \text { Jilbab } & 5 \text { Jilbab } \\ \text { Total Pendapatan } & \text { Rp. 245.000,- }\end{array}$

\section{MITRA II}

\section{Bulan Agustus}

$\begin{array}{ll}\text { Baju Gamis } & \text { 8 Baju } \\ \text { Jilbab } & \text { 25 Jilbab } \\ \text { Total Pendapatan } & \text { Rp. 895.000,- }\end{array}$

\section{Bulan September}

$\begin{array}{ll}\text { Baju Gamis } & \text { 20 Baju } \\ \text { Jilbab } & \text { 50 Jilbab } \\ \begin{array}{l}\text { Total Pendapatan } \\ \text { Bulan Oktober }\end{array} & \text { Rp. 1.945.000,- } \\ \text { Baju Gamis } & \text { 20 Baju } \\ \text { Jilbab } & \text { 50 Jilbab } \\ \text { Total Pendapatan } & \text { Rp. 2.120.000,- } \\ \begin{array}{ll}\text { Bulan November (Tanggal 7) } \\ \text { Baju Gamis }\end{array} & \text { 0 Baju } \\ \text { Jilbab } & \text { 20 Jilbab } \\ \text { Total Pendapatan } & \text { Rp. 300.000,- }\end{array}$

\section{SIMPULAN DAN SARAN}

Hasil yang dicapai IbKIK JKTM hingga bulan November 2016 (sembilan bulan) ini antara lain peningkatan motivasi usaha, peningkatan keterampilan menjahit, peningkatan aset usaha dan peningkatan manajemen usaha. Setelah mendapatkan penyuluhan kewirausahaan dari tim pengusul, baik mitra I maupun mitra II bersemangat untuk memiliki usaha sendiri yang dilakukan secara berkelompok. Hal ini merupakan peningkatan motivasi dimana sebelumnya, kegiatan sehari-hari adalah hanya sebagai ibu rumah tangga. Pemberian pelatihan menjahit yang intensif mampu meningkatkan keterampilan menjahit seluruh kelompok mitra, dimana keterampilan dasar yang pernah dimiliki tidak pernah digunakan sehingga dalam pemberian pelatihan, materi perlu diulangi kembali dari awal. Bantuan modal usaha berupa peralatan dan perlengkapan serta bahan menjahit sangat membantu untuk memulai usaha para mitra sehingga dapat meminimalisasi kerugian, karena dengan kemampuan yang sederhana tentunya kualitas produk yang dihasilkan belum sangat sempurna. Pendampingan manajemen usaha yang dilakukan tim pengusul cukup membuka wawasan kepada mitra, terutama mengenai pemasaran, dimana para mitra harus senantiasa siap menghadapi persaingan mulai dari level bawah hingga atas.

Pengasahan keterampilan menjahit perlu terus menerus dilakukan oleh mitra sehingga kualitas produk yang dihasilkan akan terus meningkat. Dengan meningkatnya kualitas produk akan membantu mitra memperluas pasarnya di tempat-tempat yang lebih besar dengan konsumen level menengah $\mathrm{ke}$ atas. Pendampingan manajemen usaha juga perlu beberapa kali dilakukan, terutama 
mengenai tren pemasaran saat ini, yaitu pemasaran online.

\section{REFERENSI}

Muchtar, AF., 2010, Panduan Praktis

Stategi Memenangkan Persaingan

Usaha dengan Menyusun Business

Plan, Elex Media Komputindo,

Jakarta 